\title{
Cross-sectoral collaboration in mental health services: Identifying the role of mental health care teams in the community
}

\author{
Osi Kusuma Sari, ${ }^{1,2, *}$ Subandi, ${ }^{1}$ and Carla Raymondalexas Marchira ${ }^{3}$ \\ ${ }^{1}$ Faculty of Psychology, Universitas Gadjah Mada, Yogyakarta, Indonesia \\ ${ }^{2}$ Directorate of Prevention and Control of Mental Health and Drugs Problems, Ministry of Health, Jakarta, Indonesia \\ ${ }^{3}$ Department of Psychiatry, Faculty of Medicine, Public Health, and Nursing, Gadjah Mada University, Yogyakarta, Indonesia
}

\section{KEYWORDS}

Community mental health

Cross-sectoral involvement

Mental health service

Mental health care teams

\begin{abstract}
Excessive Strengthening integrated and community-based mental health services is essentially needed to address the treatment gap and provide effective services that can be accessed by all groups. To realize this goal, the cross-sectoral involvement that is part of the Tim Pembina, Pengarah, dan Pelaksana Kesehatan Jiwa Masyarakat (TPKJM) is at the forefront because it has direct access to mental disorders cases in their region. This article aims to identify the role of each member of TPKJM in pursuing mental health services. Participants involved in each stage of data collection were members of TPKJM at the sub-district and village levels. The data were collected using three methods: surveys, focus group discussions, and interviews. The collected data were analyzed using an inductive thematic analysis approach to obtain a description of the role of each member of TPKJM within the case handling flow model. Five role themes were identified, including: (a) setting regulations and planning; (b) community clinical services; (c) psychoeducation; (d) safeguarding emergency cases; and (e) administrative advocacy. Regulations regarding the clarity of roles and handling flow are recommended.
\end{abstract}

(c) The Journal 2021. This article is distributed under a Creative Commons Attribution-ShareAlike 4.0 International license.

\section{Introduction}

Mental health has a substantial and significant role in a person's development. The existence of mental health problems will impact on the community by decreasing work productivity and lowering the quality of human resources. In Indonesia, mental health problems accompanied by limited access to health care contribute to unhealthy and discriminatory treatment by families, one of which is shackling. From the Primary Health Research results in $2018,14 \%$ of families have had family members with psychosis/ schizophrenia, with more cases found in families living in rural areas. Several initiatives affirm that integrating primary care to provide comprehensive, integrated, and socially responsive mental health services in community-based settings are one of the most viable options for improving public health and

\footnotetext{
*Correspondence: osikusuma@gmail.com

Faculty of Psychology, Universitas Gadjah Mada, Jl. Sosiohumaniora, Bulaksumur, Caturtunggal, Depok, Sleman, Yogyakarta 55281, Indonesia
}

addressing care gaps. ${ }^{1}$

The Comprehensive Mental Health Action Plan 2013-2020 involves launching a mental health service programs in each WHO member country, where program providers are encouraged to be more comprehensive and coordinated with various sectors, including outside the health sector, to develop integrated mental health services. ${ }^{2}$ This is done to increase mental health management's positive effect by increasing public accessibility to promotive, preventive, curative, and rehabilitative efforts. Even so, mental health care involving the community still needs to pay attention to the needs of service users and be adjusted to the readiness of service providers with several ideal criteria. ${ }^{3}$

Mental health problems that occur in Indonesia require appropriate strategies to address mental health care disparities. The increase in the prevalence of mental disorders that are not accompanied by a sufficient number of professionals to meet the needs of mental health services can create other socio- 
Table 1. Mental Health Professionals in Province DIY

\begin{tabular}{lllll}
\hline No & Regencies / Cities & Nurse & $\begin{array}{l}\text { Psycho- } \\
\text { logist }\end{array}$ & $\begin{array}{l}\text { Psychi- } \\
\text { atrist }\end{array}$ \\
\hline 1 & Yogyakarta & 6 & 11 & 5 \\
2 & Sleman & 20 & 23 & 10 \\
3 & Kulonprogo & 6 & 0 & 1 \\
4 & Gunung Kidul & 2 & 0 & 1 \\
5 & Bantul & 14 & 0 & 1 \\
& Total & 48 & 34 & 18 \\
\hline
\end{tabular}

Source: Provincial Mental Health Data DIY, 2016

health problems. In the Special Region of Yogyakarta, with the highest prevalence of mental disorders in 2018 in Indonesia, treatment gaps were also found. Table 1 shows the total number of mental health personnel in DIY with 48 nurses, 34 psychologists and 18 psychiatrists are not sufficient to meet the needs of more than 3.5 million people. The prevalence ratio of these health workers is still far below the average mental health worker survey results in 135 WHO member countries, namely 9 (nine) mental health workers per 100,000 population. ${ }^{4}$

Referring to a survey conducted by the World Psychiatric Association (WPA) in 60 countries, three strategies are recommended to reduce this gap, namely: (i) by increasing the number of psychiatrists and mental health professionals who are evenly distributed; (ii) increasing the involvement of trained non-specialist mental health service providers; and (iii) increasing the active involvement of people affected by mental disorders, both people with health problems (ODMK) directly and their families and surrounding communities. ${ }^{5}$ These recommendations were welcomed by the Ministry of Health of the Republic of Indonesia (MOH RI). In 2002, the $\mathrm{MOH}$ $\mathrm{RI}$ attempted to provide regulatory support and community mental health programs through the formation of a Community Mental Health Advisory, and Implementation Team (TPKJM) ${ }^{6}$ which involved cross-sectoral and community support, supported by the Health Alert Village regulation ${ }^{7}$ and community mental health services. ${ }^{8}$ The TPKJM is a means that provides space for cross-sectoral and community members to contribute to efforts to address care gaps in mental health. Several districts in Indonesia have established TPKJM, although their roles are not yet optimal. ${ }^{9-12}$ Not all regions in Indonesia can implement the TPKJM guidelines, ${ }^{6}$ so their roles differ in each region. Accordingly, this research was conducted to explore the operational TPKJM work model that was already running, with a more technical workflow. Community mental health efforts will be achieved if the TPKJM can have a clear and proactive role and function by its formation objectives. ${ }^{13}$

Kulonprogo Regency is one of the districts in DIY with high case findings of mental disorders. The regency seeks to develop Community-Based Mental Health Efforts (UKJBM) by encouraging the existence of TPKJM in sub-districts and villages. However, its implementation still requires clear guidelines and precision in the flow in handling the cases at hand. The limitations of research and studies related to this area are some of the problematic aspects that encourage the author to research TPKJM activities. These efforts are focused at the sub-district to village level in Kulonprogo Regency in mental health efforts in this region referring to existing regulations, ${ }^{14}$ by involving community members that may help to bridge the limited access to existing health service facilities.

The main research question posed is how does each TPKJM member's involvement in all sectors provide mental health services. This research will explore the TPKJM availability in the region and the models of cases being handled. Identification related to each TPKJM member's role will provide an overview of the flow of case handling that involves cross-sector collaboration. This research will enrich the literature review and can support the development of mental health efforts in Indonesia.

\section{Method}

This research is part of a research project on the implementation of recovery-oriented mental health services in Kulonprogo Regency, which is a collaborative research project of the Faculty of Psychology, Faculty of Medicine, Public Health and Nursing, Universitas Gadjah Mada (UGM), and Harvard Medical School, as well as the Kulonprogo District Health Office. The design used in this study was an exploratory design with a qualitative approach. Creswell argues this method can produce data that will be more complete, more profound, credible, 
and meaningful because the approach can explore data that include a work process, the development of an activity, a broad and deep description, feelings, norms, mental attitudes, beliefs, work ethic and culture embraced by individuals and groups of people in the work environment. ${ }^{15}$ With these steps, the objectives of the research can be achieved. Data collection was done in three stages.

First, the researchers obtained data on the availability of the TPKJM through a survey in conjunction with the initial situation analysis and data collection for the development of recovery-oriented mental health services in Kulonprogo Regency at the end of 2018. The survey was conducted in all 21 community health centers (Puskesmas) in the Kulonprogo district $(n=21)$, and as informants there were health workers in each of these Puskesmas. In this first stage, document analysis of several related health regulations was also done including, institutional documents, institutional decree, guidelines, service guidelines, and other related sources. The data obtained formed the basis for purposeful sampling ${ }^{15}$ at a later stage.

Second, focus group discussions (FGDs) were conducted to deepen the survey results. Participants who were involved were based on their participation in the TPKJM at the sub-district and village levels based on the results of the survey in the first phase. During the FGDs, information was extracted regarding the background of the formation of the village TPKJM, workflow, supervision, membership, regular meetings, sources of funds, the areas of cases being handled, obstacles, and expectations about the TPKJM activities that are currently running.

Third, exploratory interviews were done to validate the results. A total of nine $(n=9)$ participants were involved in these interviews. This stage involved $(n=9)$ participants who were selected to represent each agency in the TPKJM SK. Based on recommendations from informants who were stakeholders, they were involved and had experience in their capacity to participate in implementing community mental health efforts in their area. Each participant represents a profession or an institution in the TPKJM membership. Characteristics of the participants are shown in Table 2.
Table 2. Characteristics of participants $(n=9)$

\begin{tabular}{lll}
\hline Criteria & $\mathrm{n}$ & $(\%)$ \\
\hline Age & & \\
$31-40$ years & 5 & 56 \\
$41-50$ years & 3 & 33 \\
$51-60$ years & 1 & 11 \\
Gender & & \\
$\quad$ Man & 5 & 56 \\
$\quad$ Woman & 4 & 44 \\
Education Degree & & \\
$\quad$ High School & 4 & 45 \\
$\quad$ Diploma & 3 & 33 \\
$\quad$ Bachelor & 2 & 22 \\
Job & & \\
$\quad$ Civil Services & 5 & 56 \\
$\quad$ Non-permanent Civil Services & 4 & 44 \\
Profession (at institution) & & \\
$\quad$ Head of Primary Health care (Puskesmas) & 1 & 11 \\
$\quad$ Nurse (mental health programmer) & 1 & 11 \\
Head of Village & 1 & 11 \\
Village police (Babinkamtibmas) & 1 & 11 \\
Head of sub village & 2 & 23 \\
TKSK (District Social Welfare Workers) & 1 & 11 \\
Welfare section (Kaur Kesra) & 1 & 11 \\
$\quad$ Mental health worker & 1 & 11 \\
\hline Total & 9 & 100 \\
\hline
\end{tabular}

All data collection was conducted until November 2019 with ethical approval from the Medical and Health Research Ethics Committee of the Faculty of Medicine, Public Health, and Nursing Research, UGM. The principles of voluntary ethics, anonymity, confidentiality, and respect were applied in this study.

\section{Result}

The TPKJM presence survey conducted at 21 subdistrict health centers $(n=21)$ helped determine the criteria for participants to be involved in the next stage, namely FGDs and interviews. From each participant's answer in the FGD and interviews, then transcription was done for analysis using an inductive thematic analysis approach with six stages of coding and theme development (Braun \& Clarke, 2006). The analysis does not ignore social constructionism, acknowledging the complexity of individual experience and the importance of a broader context. The themes identified are presented in sections 
according to the research question. The following is a description of the findings from the survey results and interviews that have been conducted.

\subsection{Other sources of support do not accompany the availability of the TPKJM}

In all Puskesmas working areas, in all sub-districts in Kulonprogo district (100\%) a sub-district level TPKJM has been established. However, of this number, there were two TPKJMs (10\%) that had not yet received a Kecamatan TPKJM SK's decree which is important as a legal force that gives authority to the members involved in their duties. The availability of data and an overview of TPKJM activities are shown in Table 3.

Table 3 shows that almost all of the sub-district TPKJM (95\%) had regular meetings in the past year. Matters that are often discussed in routine meetings are related to referral difficulties, both new and old cases $(90 \%)$, new case findings ( $86 \%)$, and the need for support from other sectors (76\%). In conducting each of its activities, the TPKJM received funding that is allocated from BOK fund, village funds, and from Puskesmas funds. When viewed from the urgency of discussion in meetings, the frequency of meetings is considered insufficient. This gap is due to the lack of attention from supporting resources, such as financing and prioritizing of mental health service activities.

This February has not [regular meeting]. BOK has not yet come down, so we cannot hold a meeting yet. Because the program's spirit is not "in" [not main / priority], it is different from stunting, malnutrition, and pregnant women. The soul is only such a number program so that the funds are small.(Mental health programmer)

The data above show that almost all TPKJM subdistricts, totaling 19 out of 21 existing sub-districts (90\%), are involved in handling emergency cases. These data are also supported by a statement from one of the TPKJM members as follows:

So far, what the TPKJM has been doing is still handling severe mental disorders that already exist. There is no or maybe rarely in the
Table 3. Survey of Community Health Centers in Kulonprogo District ( $\mathrm{n}=21$ )

\begin{tabular}{|c|c|c|}
\hline Availability and Activities TPKJM & $\mathbf{n}$ & $\%$ \\
\hline \multicolumn{3}{|l|}{ Availability TPKJM at sub District } \\
\hline Yes & 21 & $100 \%$ \\
\hline \multicolumn{3}{|l|}{ No } \\
\hline \multicolumn{3}{|l|}{ Legitimacy of TPKJM Sub district } \\
\hline Yes & 19 & $90 \%$ \\
\hline No & 2 & $10 \%$ \\
\hline \multicolumn{3}{|l|}{ Regular meeting per year } \\
\hline Yes & 20 & $95 \%$ \\
\hline No & 1 & $5 \%$ \\
\hline \multicolumn{3}{|l|}{ Number of meeting per year } \\
\hline None & 1 & $5 \%$ \\
\hline once & 11 & $52 \%$ \\
\hline twice & 9 & $43 \%$ \\
\hline \multicolumn{3}{|l|}{ Topic of meeting } \\
\hline New Cases & 18 & $86 \%$ \\
\hline $\begin{array}{l}\text { Difficulty in referencing new / old } \\
\text { cases }\end{array}$ & 19 & $90 \%$ \\
\hline $\begin{array}{l}\text { The need for support from other } \\
\text { sectors }\end{array}$ & 16 & $76 \%$ \\
\hline Other & 3 & $14 \%$ \\
\hline \multicolumn{3}{|l|}{ Source of fund } \\
\hline BOK & 19 & $90 \%$ \\
\hline Village fund & 1 & $5 \%$ \\
\hline PKM Fund & 1 & $5 \%$ \\
\hline \multicolumn{3}{|l|}{ Handled severe cases } \\
\hline Yes & 19 & $90 \%$ \\
\hline No & 2 & $10 \%$ \\
\hline \multicolumn{3}{|l|}{ Availability TPKJM at Village } \\
\hline Yes & 4 & $19 \%$ \\
\hline No & 17 & $81 \%$ \\
\hline \multicolumn{3}{|l|}{ Availability DSSJ (Desa Siaga Sehat Jiwa) } \\
\hline Yes & 2 & $10 \%$ \\
\hline No & 19 & $90 \%$ \\
\hline Total & 21 & $100 \%$ \\
\hline
\end{tabular}

handling of other new mental health problems. (Mental health programmer)

Of the 19 existing sub-district TPKJMs, 4 of them have established village TPKJMs and 2 (two) other sub-district TPKJMs also have Alert Healthy Mental Villages (DSSJ), which assist sub-district 
TPKJM activities. With this condition, a mental health implementation team involves cross-sectoral support at the sub-district to village level, providing an easy reach of services in helping and handling cases of mental disorders in the community. In this case, what is handled are the troubling emergency cases.

\subsection{Availability of TPKJM at village}

The willingness of stakeholders to form TPKJM down to the village level and play a role in conducting its activities needs to be appreciated. The initiative for the TPKJM at the village level originated from the community's complaints regarding ODGJ (People with Soul Disorders) in their environment, who caused unrest.

Because around the $S^{* *}$ area, there are many cases of mental disorder that most disturbs the environment. In terms of handling the patient's right and left, they do not know what method, the right way, and the procedures. The TPKJM team continues to be formed (Village police)

Judging from the administrative and coordination structure, the village TPKJM is indeed under the sub-district TPKJM. However, in implementing its programs and activities, it is necessary to have rules as guidelines. Based on the results of the situation analysis survey that the researchers conducted before, all village TPKJM in Kulonprogo already have supporting regulations from the village TPKJM decree, which is guided by the sub-district TPKJM decree.

The village head chairs the village TPKJM, and the membership consists of village officials, community and religious leaders, and several representatives from related institutions. Some of the institutions involved include Puskesmas, social institutions such as the TKSK / KPKD, and security forces such as Babinsa and Babinkamtibmnas. Therefore, the availability of TPKJM at the village level becomes a necessity when the sub-district TPKJM is still unable to directly address cases in the community due to the difficulty of tiered coordination with the administrative institutions under it, namely the village.

\subsection{TPKJM needed in the handling of cases of severe mental disorders in the community}

The survey found that 19 TPKJM sub-districts (90\%) were involved in handling emergency cases, because there are often cases of severe mental disorders that go berserk or aggressively cause disturbances in the community, so that direct involvement from competent parties is needed. Participants said that there was no involvement of the TPKJM in cases or management of other mental disorders.

So far, it has not reached that direction (handling of other cases); indeed, the involvement of the TPKJM is only in the handling of severe ODGJ cases, it has not yet reached (handling other issues), yes Insyaallah in the future. (mental health programmer)

In handling emergency cases, the TPKJM team must coordinate with each other among the village government, mental health workers, programmers at Puskesmas, and Babinsa, and also Babinkamtibmas. The findings of emergency cases by health workers, for example, are reported to the head of the local neighborhood in village and then reported to their Puskesmas and the police for handling assistance. Coordination with the TKSK or KPKD (Regional Poverty Prevention worker) is also needed to assist with administrative requirements, especially for patients without identity and health insurance or KIS.

If something happens, the health worker of souls will report to the dukuh, the dukuh to the People's Welfare, the Lurah, and then work with the Puskesmas. Same with the police (also) usually.

Those who already have KIS are easy. We do not need to walk around here and there. However, all this time, we have taken care of our health insurance together with our friends from the KPKD [Regional Poverty Prevention workers]. (Mental health worker) 
Even though the implementation is still limited to handling emergency cases, TPKJM members hope to be involved in handling other cases. Participants expressed their desire to be involved in comprehensive services to rehabilitative efforts in the community. This can be seen as an opportunity in the development of community mental health services.

Suppose the TPKJM is comprehensive, in my opinion. So, it is not only (cases) of schizophrenia, depression, but also community empowerment to join ODGJ. Not only (severe cases, referred to, but yes, that was, like the 10 (ten) houses around ODGJ lives, also motivated the community to be involved in helping people affected by mental disorders. Then to RBM [Community Based Rehabilitation] and $O D G J$ can be independent. My dream like that. (mental health programmer)

\subsection{Cross-sector membership makes each contribution}

Many TPKJM members need a clear division of roles according to their respective professions' competence and authority. Even though they already have a decree of TPKJM, both at the sub-district and village level, the division of roles according to conditions in the field has not been explained in detail. Therefore, the author tried to explore the roles and involvement of each in the FGD and interviews. Role identification was not only during case handling but also during the functioning of the TPKJM. From the results of the exploratory evaluation, the writer then divided them into 5 (five) groups of the themes of the roles and holders of their roles according to the areas they are handling, as shown in Table 4

In determining regulations and planning, the role of the government/village officials is the main governing body. Following their authority and competence, government officials can conduct program planning, budgeting, and inventory of patient administration completeness, which are very much needed in mental health services and for the smooth running of the TPKJM activities itself. This official supervision is also inseparable from the pamong's position as supervisors in the TPKJM membership.
The role of community clinical services by the TPKJM had become a significant role by the background of the formation of the TPKJM. Referring to their authority and competence, formal or trained health workers have a more significant responsibility. This role emphasizes the ability to identify cases of mental disorders, early detection, clinical management, referral bureaucracy, and case reporting. In a non-clinical context, in general, this role is the responsibility of the TPKJM members.

The role of psychoeducation is needed to approach and understand families and communities to support every TPKJM effort in handling mental disorders. Meanwhile, the stigma of family and society towards ODGJ is perceived as an obstacle in handling cases, as revealed by the following participants.

Well, the hamlet himself was overwhelmed by that. In the sense of giving advice, doing things with good intentions, but from the family side, there is no response.

Because, frankly, what often happens is that people around them find that people like that are less concerned, less educated, and are just left alone. And maybe (needed) understanding also to the ODGJ family. (Social worker).

This role emphasizes the mental health literacy skills of related actors to provide proper understanding to families and the general public. The involvement of religious and community leaders is needed because a public figure is generally obeyed by the community.

The role in securing emergency cases requires the involvement of security forces, such as Babinsa and Babinkamtibmas. One of the reasons for this is how the public's perceptions of the security forces' presence can make them more or less obedient. Apart from helping to alleviate the chaotic conditions caused by a rampaging ODGJ, the security forces also assisted in escorting referrals to hospitals.

Sometimes ODGJ even sees babinsa or bhabinkamtibmas when mentally down. They do not dare to go berserk anymore. 
Table 4. Findings of the theme of roles and stakeholders of TPKJM

\begin{tabular}{llll}
\hline No & Role Theme & Role Description & Role Holder \\
\hline 1 & $\begin{array}{l}\text { Setting regulations and } \\
\text { planning }\end{array}$ & $\begin{array}{l}\text { Carry out program planning and budgeting to inventory } \\
\text { the completeness of patient administration as residents } \\
\text { who will affect operations and handling costs. }\end{array}$ & $\begin{array}{l}\text { Headman, welfare section, } \\
\text { carik, and other village } \\
\text { officials. }\end{array}$ \\
\hline 2 & $\begin{array}{l}\text { Community clinical } \\
\text { services }\end{array}$ & $\begin{array}{l}\text { Identify problems/cases of mental disorders faced by } \\
\text { early detection, clinical handling, referral bureaucracy, } \\
\text { to recording case reports. }\end{array}$ & $\begin{array}{l}\text { Mental health worker, } \\
\text { nurse, or another health } \\
\text { professional. }\end{array}$ \\
\hline 3 & Psychoeducation & $\begin{array}{l}\text { Conducting approaches/advocacy to patients, families, } \\
\text { and communities through persuasive action and } \\
\text { psychoeducation. }\end{array}$ & $\begin{array}{l}\text { Neighborhood/citizen } \\
\text { association, Hamlet, Dukuh, } \\
\text { religious leader, women } \\
\text { association }\end{array}$ \\
\hline 4 & $\begin{array}{l}\text { Handling of emergency } \\
\text { cases }\end{array}$ & $\begin{array}{l}\text { To anticipate security, escort, and safeguard against the } \\
\text { possibility of security disturbances in the work area due } \\
\text { to the problem of the mental disorder case. }\end{array}$ & $\begin{array}{l}\text { Security from village army } \\
\text { and police called Babinsa } \\
\text { and Babinkamtibmas }\end{array}$ \\
\hline 5 & Administrative advocacy & $\begin{array}{l}\text { Assisting in the administration and the person in charge } \\
\text { of filing the patient to making a domicile letter for } \\
\text { patients without complete identity/health insurance. }\end{array}$ & TKSK/ KPKD \\
& & &
\end{tabular}

Now it is a coincidence that from babinsa or bhabinkamtibmas, that is an obligation. Babinkamtibmas maintains order in the community, while sometimes ODGJ gets mad in society. They may go berserk when people cannot resist their emotions, and people react, sometimes some beat ODGJ. So, we need babinsa or bhabinkamtibmas to put things in order like that. If anyone is anarchist or something...., (Village police)

The role of administrative advocacy, such as handling a domicile letter by TKSK, is needed for ODGJ. They do not have complete identities so that they can access local mental health services. In addition, administrative advocacy is also needed to assist ODGJ who do not have regional health insurance so that they get an allocation from social health insurance. Such assistance helps ODGJ, especially ODGJ with low social, economic status (SES), in financing access to mental health services.

TKSK is our spearhead. A place where we complain and where we share. If ODGJ does not have an identity (KTP), I ask TKSK to make a domicile certificate.

Because we do not have health insurance, in the Progo Kulon, there is a Progo Kulon $A P B D$. We will enter it. Who knows when the proposal has entered the baseline. If it has entered the database, we bring a photocopy of the card, the written ID card, the person concerned, we bring it to Jamkesda there is a recommendation to print the card we take to BPJS. We usually make the identification of these documents before they are brought to Grhasia. But if there is no check at Jamkesda, we will try to go to Jamkesos by TKSK...(TKSKSocial worker)

Based on the various roles that each TPKJM member has, it is clear that multi-sector involvement provides much convenience in mental health services in the community. Therefore, coherent coordination and collaboration are required. Unfortunately, participants in this study identified the lack of coordination between sectors that have occurred so far, which has become an obstacle in service delivery.

coordination..... probably less coherent coordination, from the village, district, or from the clinic (Puskesmas).....

The following illustrates an outline of cross-sectoral involvement in case handling in Figure 1.

\section{Discussion}

This article is a preliminary study to explore the field potential in the development of recovery-oriented mental health services in Kulonprogo district. The availability of the TPKJM in all sub-districts, even to the village level in several areas, is an opportunity and a challenge in bridging the gap in treating 


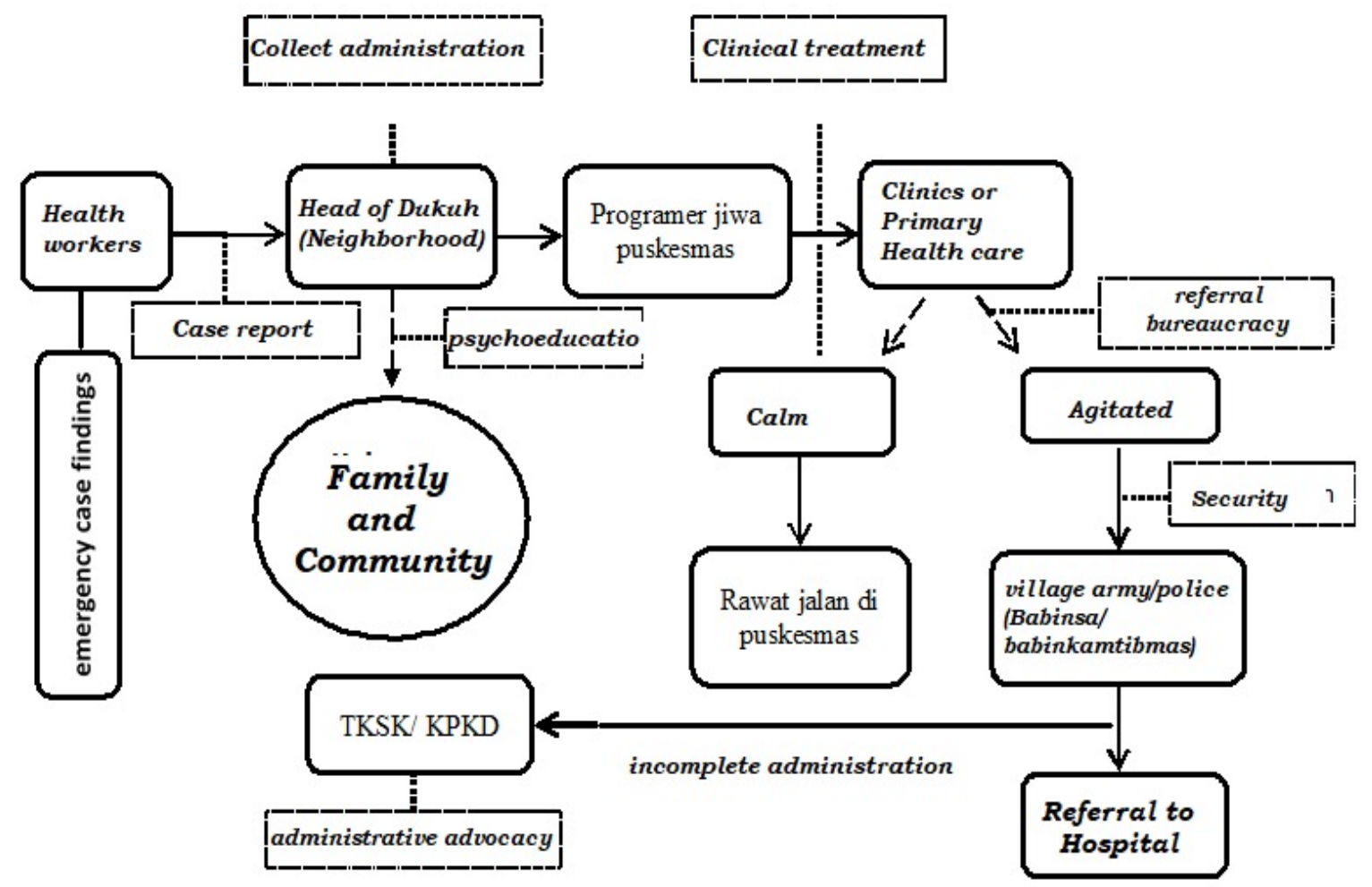

Figure 1. Flow of Roles and Handling of Emergency Cases by TPKJM

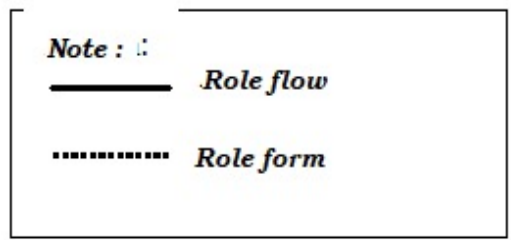

mental disorders in the community. This is done in collaboration in handling emergency cases, assisting access to health services, and advocating for financing. Community involvement in strengthening the mental health system has become the primary key supported by the reviewed evidence. . $^{15,16}$

Some low- and middle-income countries run community-based services, and the impact is recognized to support accessible care for people with mental illness (ODGJ) with low socioeconomic conditions. ${ }^{17}$ High maintenance costs, inadequate transportation infrastructure, and a lack of economic resources to access transportation necessitate community-based services. ${ }^{18,19}$ In this model, the leading institutions, namely the local health office and hospitals in the region, are responsible for strengthening human resources capable of reaching remote locations, ${ }^{20}$ improving supporting facilities and infrastructure, and encouraging communities and institutions' contribution across sectors.

The increased desire and awareness to be involved in mental health services among all components is the main point that needs to be criticized considering that there is no clarity on the role and flow of handling as a regulation. Previous studies found challenges in reaching agreement among cross-sector teams, including concerns about involving non-professional trained health workers in mental health services. ${ }^{21,22}$ Clarity and sharing of understanding among service providers regarding the purpose of involvement helps the success of community mental health services. ${ }^{23}$ These findings 
indicate the need to clarify this gap at this point in time. Until now, the implementation of cross-sectoral teamwork has tended to focus on willingness of time and volunteering, rather than as a professional and institutional responsibility to be active and genuinely engaged in activities. This study identifies the need to consider a more holistic regulation that includes the roles and flows of institutional and environmental efforts, and individual engagement to achieve optimal levels of engagement.

Another interesting finding is that the involvement of the TPKJM in the care of ODGJ is not only a professional responsibility but also part of the wider community effort, including community leaders, local government, police, and neighbors. The formation of mental health care in which local community members are trained in providing primary mental health care is viewed positively to meet ODGJ and caregivers' needs and to increase empowerment in the community. This approach is in line with previous studies related to the involvement of ordinary people in supporting service inclusiveness. ${ }^{5,24,25}$ This identification proves that the collective culture that characterizes the Indonesian context has the potential to overcome failures in community engagement. ${ }^{26,27}$

Although the potential benefits of having the TPKJM have been recognized, implementation in the field is still limited, and obstacles have been found. In this study, negative attitudes towards mental health providers were identified as a barrier to developing community-based mental health services through the TPKJM. At the health care system level, a lack of priority for mental health was identified, with inequitable access to mental health facilities, and a complicated bureaucracy for accessing services. At the service provider level, a lack of commitment and capability to provide services was also identified. At the community level, identified stigma and discrimination still hinder involvement in supporting services. Therefore, a more substantial commitment, both from human resources, regulations, and other supporting resources, is needed to support each TPKJM activity. Various studies identify the need to increase community involvement in mental health services. It is essential to increase mental health awareness among policy makers, improve coordination between government agencies, and support leadership at higher levels. (Irmansyah, 2020). Likewise, there needs to be further consideration of the existence of stigma and discrimination toward ODGJ in the community and among service providers. ${ }^{28-30}$

\section{Conclusions}

The optimal role and performance of the TPKJM in all regions, down to sub-districts and even villages, will need more substantial support from human resources, funding, and regulations from local authorities. Community mental health efforts through optimizing the performance of the TPKJM require guidelines that provide a reference and clarity for the workflow of each team member. With the support of regulations and standard operating procedures, this approach will encourage cross-sectoral involvement, increase community awareness and participation, and engage the government officials' responsibility down to the village level.

\section{Acknowledgement}

The author would like to express his gratitude to the Faculty of Psychology, Universitas Gadjah Mada through the internship program so that the author can compile this article's writing, along with the support of facilities and access to existing literature.

\section{Conflict of interests}

The author discloses the following receipt of financial support for research, authorship, and publication of this article from a collaborative research project to strengthen the mental health system in Indonesia in collaboration with the Faculty of Psychology, the Faculty of Medicine, Public Health and Nursing UGM and Harvard Medical School, and the Kulonprogo District Health Office.

\section{References}

1. Brooks H, James K, Irmansyah I, Keliat BA, Utomo B, Rose $D$, et al. Exploring the potential of civic engagement to strengthen mental health systems in Indonesia (IGNITE): a study protocol. Int J Ment Health Syst. 2018;12:49. 
2. WHO. Comprehensive mental health action plan 2013-2020 [Internet]. Eastern Mediterranean Health Journal. Geneva: World Health Organization; 2013. Available from: http://apps. who.int/gb/ebwha/pdf_files/WHA66/A66_R8en.pdf.

3. Bouras N, Ikkos G, Craig T. From community to meta-community mental health care. Int J Environ Res Public Health. 2018;15(4):806.

4. World Health Organization. Global Health Observatory (GHO): Mental health workers Data by country [Internet]. GHO. 2018 [cited 2019 Sep 9]. Available from: https://apps.who.int/ gho/data/view.main.HWF11v

5. Patel V, Maj M, Flisher AJ, De Silva MJ, Koschorke M, Prince M; WPA Zonal and Member Society Representatives. Reducing the treatment gap for mental disorders: a WPA survey. World Psychiatry. 2010 Oct;9(3):169-76.

6. Depkes RI. Kepmenkes No. 220/MENKES/SK/ III/2002 Tentang Pedoman Umum Tim Pembina, Tim Pengarah, Tim Pelaksana Kesehatan Jiwa Masyarakat ( TP KJM ). Jakarta: Depkes Rl; 2002.

7. Kemenkes RI. KMK No. 1529/Menkes/SK/X/2010 tentang Pedoman Umum Pengembangan Desa Dan Kelurahan Siaga Aktif. Jakarta: Kemenkes Rl; 2010.

8. Depkes RI. Kepmenkes No. 406/Menkes/SK/ $\mathrm{VI} / 2009$ Tentang Pedoman Pelayanan Kesehatan JIwa Komunitas. Jakarta: Depkes RI; 2009.

9. Esem O. Perlindungan Hak Atas Pelayanan Kesehatan Bagi Orang Dengan Gangguan Jiwa Di Daerah Istimewa Yogyakarta Berdasarkan Undang Undang Nomor 18 Tahun 2014 Tentang Kesehatan Jiwa. Chmk Heal J. 2019;3.

10. Sunarno I. Model Pemberdayaan Masyarakat Dalam Pembebasan Pasung Menurut Perspektif Budaya Jawa. J Keperawatan Terap. 2018;4, NO. 1,(Maret 2018):27-43.

11. Tyas TH, Faturochman TH, Tyas W, M Minza. Pasung sebagai isu kesehatan jiwa di Indonesia dalam Psikologi untuk kesejahteraan masyarakat. Yogyakarta: Pustaka Pelajar; 2012. 186-211 p.

12. Wahyudi A, Fibriana A. Faktor resiko terjadinya shizofrenia (studi kasus di wilayah kerja
Puskesmas Pati II). Public Heal Perspect J. 2016;1.

13. Yanasari P. Implementassi Peraturan Gubernur DIY No. 81 tahun 2014 Tentang Pembebasan Pasung Bagi ODGJ. Yogyakarta: Thesis: Tidak dipublikasikan; 2017.

14. Kemenkes RI. Pedoman umum program indonesia sehat dengan pendekatan Keluarga. Jakarta: Kemenkes RI; 2016.

15. Brett J, Staniszewska S, Mockford C, Herron-Marx $\mathrm{S}$, Hughes J, Tysall $\mathrm{C}$, et al. Mapping the impact of patient and public involvement on health and social care research: A systematic review. Heal Expect. 2014;17(5):637-50.

16. Luszczynska A, Benight CC, Cieslak R. Self-efficacy and health-related outcomes of collective trauma: A systematic review. European Psychologist. 2009; 14(1):51-62.

17. Kohrt BA, Asher L, Bhardwaj A, Fazel M, Jordans MJD, Mutamba BB, Nadkarni A, Pedersen GA, Singla DR, Patel $V$. The role of communities in mental health care in low- and middle-income countries: A meta-review of components and competencies. Int J Environ Res Public Health. 2018; 16;15(6):1279.

18. Singla DR, Kohrt BA, Murray LK, Anand A, Chorpita BF, Patel V. Psychological treatments for the world: Lessons from low- and middleincome countries. Annu Rev Clin Psychol. 2017;13(1):149-81.

19. Mutamba BB, Van Ginneken N, Smith Paintain L, Wandiembe S, Schellenberg D. Roles and effectiveness of lay community health workers in the prevention of mental, neurological and substance use disorders in low and middle income countries: A systematic review. BMC Health Serv Res. 2013;13(1).

20. Patel V. The future of psychiatry in low-and middle-income countries. Psychological Medicine. 2009.

21. Marastuti A, Subandi MA, Retnowati S, Marchira CR, Yuen CM, Good BJ, et al. Development and Evaluation of a Mental Health Training Program for Community Health Workers in Indonesia. Community Ment Health J. 2020;(0123456789).

22. Mendenhall E, De Silva MJ, Hanlon C, Petersen 
I, Shidhaye R, Jordans M, et al. Acceptability and feasibility of using non-specialist health workers to deliver mental health care: Stakeholder perceptions from the PRIME district sites in Ethiopia, India, Nepal, South Africa, and Uganda. Soc Sci Med. 2014;118(C):33-42.

23. Carpenter J, Schneider J, Brandon T, Wooff D. Working in multidisciplinary community mental health teams: The impact on social workers and health professionals of integrated mental health care. Br J Soc Work. 2003;33(8):1081-103.

24. Patel V, Weiss HA, Chowdhary N, Naik S, Pednekar S, Chatterjee $S$, et al. Lay health worker led intervention for depressive and anxiety disorders in India: Impact on clinical and disability outcomes over 12 months. $\mathrm{Br} J$ Psychiatry. 2011;199(6):459-66.

25. Allen CG, Sugarman MA, Wennerstrom A. Community health workers: a resource to support antipsychotic medication adherence. J Behav Heal Serv Res. 2017;44(2):341-6. Available from: http://dx.doi.org/10.1007/ s11414-016-9515-x

26. Susanti $H$, James $K$, Utomo B, Keliat BA, Lovell $\mathrm{K}$, Irmansyah $\mathrm{I}$, et al. Exploring the potential use of patient and public involvement to strengthen Indonesian mental health care for people with psychosis: A qualitative exploration of the views of service users and carers. Heal Expect. 2020;23(2):377-87.

27. Irmansyah I, Susanti H, James K, Lovell K, Idaiani $S$, Imah $S$, et al. Civic engagement and mental health system strengthening in Indonesia: A qualitative examination of the views of health professionals and national key stakeholders. BMC Psychiatry. 2020;20(1):1-15.

28. Kleintjes S, Lund C, Swartz L. Barriers to the participation of people with psychosocial disability in mental health policy development in South Africa: A qualitative study of perspectives of policy makers, professionals, religious leaders, and academics. BMC Int Health Hum Rights. 2013;13(1):7-11.

29. Pugh T, Hatzenbuehler M, Link BG. Structural stigma and mental illness. Stud Heal Technol Inf. 2015;192(October):1-71.
30. Lempp H, Abayneh S, Gurung D, Kola L, Abdulmalik J, Evans-Lacko $S$, et al. Service user and caregiver involvement in mental health system strengthening in low- and middle-income countries: A cross-country qualitative study. Epidemiol Psychiatr Sci. 2018;27(1):29-39. 